\title{
17. Accounting for the Sources of Growth in Chinese Industry, 1980-2010'
}

Harry X. Wu

\section{Introduction}

Although China's reform has been unquestionably market-oriented in general, it has not yet reduced the role of the Government in business. In fact, the resurgence of consolidated and enlarged state-owned enterprises (SOEs) in so-called 'strategic industries' and the increasing government interventions in resource allocation since the mid 2000s, especially following the GFC in 2008, have remained at the centre of policy debate concerning further and deeper structural reforms. What has been missing in the debate, however, is the productivity performance of industries or sectors with different degrees of state involvement and interference. By abandoning the command economy and encouraging activities to reap China's comparative advantage, the Chinese Government has (so far) successfully solved the growth problem, but it remains unclear whether strong state interventions have also solved the inefficiency problem and hence have been able to promote genuine productivity growth.

Despite numerous empirical studies attempting to account for the sources of growth in the Chinese economy, there has been no consensus among scholars on China's post-reform productivity performance. Empirical studies have shown that the estimated contribution of total factor productivity (TFP) to China's GDP growth in the post-reform period (though not with an identical duration) ranges from negative to as high as more than 50 per cent (see reviews in Wu 2011; Wu 2014a). We may argue that since almost all of these studies adopted the same neoclassical growth accounting framework, the contradictory estimates of China's TFP growth clearly and logically suggest that there are serious problems with data and measurement. Indeed, I have shown that using exactly the same

1 Reported in this chapter are the interim results of the author's ongoing China Industrial Productivity (CIP) and China KLEMS Database projects. The CIP/China KLEMS project aims to construct input and output data for standard growth and productivity analysis. Support from RIETI, IER of Hitotsubashi University, the Japanese National Science Foundation (JSPS 24330076) and The Conference Board (TCB) China Center is gratefully acknowledged. Part of the work presented in this chapter has benefited from comments and suggestions at the first and second World KLEMS conferences at Harvard University. The author is responsible for any error or omission. 
input and output data, the different choices of output measures, investment deflators, as well as factor income shares, can result in very different estimates of the TFP growth for the aggregate economy (Wu 2014a).

Nevertheless, to address the productivity problem and to relate it to the policy debate over future reform, we need to examine the industry-level rather than the aggregate-level TFP performance of the Chinese economy. This is because we are interested in the role of the Government, which may be captured, though indirectly, by the productivity performance of state-monopolised or influenced industries. After all, government interventions are often made through industryspecific policies and related institutional arrangements. Our newly constructed industry-level data for the period 1980-2010 serve this purpose.

The rest of the chapter will be organised as follows. In section two, I conceptually discuss the role of the Government in the Chinese economy to support my datum handling for industry grouping later. In the subsequent section, I discuss the methodological issues that are considered for economywide coherence in input, output and the costs of factor and intermediate inputs, as well as the inter-industry cumulative effect of productivity changes. In section four, following the earlier conceptual discussion and the feature of the Domar aggregation approach, I introduce the industry grouping as well as the data used. Finally, I present and discuss the results in section five and conclude this study in section six.

\section{Considering the role of the Government}

My main objective here is to examine whether government involvement has affected the productivity performance of the Chinese economy. This is challenging because policy or institutional factors are not an inherent part of the standard theory of production function; however, government policy is industry-specific and industries are connected through vertical input-output links. Therefore, to explore the role of the Government, I first distinguish industries with different types of government interventions and then explore their productivity implications and how the aggregate industrial economy is affected.

Despite a significant decline of the state sector over the reform period, governments at all levels have maintained strong intervention in the allocation of resources to support the so-called strategic industries, of which the majority are either owned or heavily influenced by the state. One important change with reform, however, is that government intervention is no longer all embracing, as it was in the central planning era, which completely ignored the market. It has become industry-specific through subsidisation, administrative interference or 
both. Subsidisation aims to reduce producers' costs of inputs including energy, land, environment, labour and capital (see Huang and Tao 2010). In contrast, administrative interference aims to serve the state's interests and state 'strategic plans' by controlling or influencing output prices or various aspects of business operations from managerial personnel to the choice of technology.

I argue that whether or to what extent governments use administrative interference or subsidies depends on the distance of an industry from final demand, especially the international market. Local governments use subsidisation mainly to promote export-oriented industries that produce semifinished and finished goods. These industries are mainly labour intensive and therefore crucial for China to reap its demographic dividend in a timely fashion. Since these industries face international competition, direct administrative interference is counterproductive; however, the Central Government or higherlevel authorities tend to become directly involved in upstream industries because they are considered strategically important to sustain the growth of downstream industries. Administrative measures such as managerial and price controls are used to ensure that upstream industries can provide sufficient and cheap supplies to downstream industries. Nevertheless, subsidisation could also be used to support upstream industries whenever administrative interference is not cost-effective.

Considering the behaviour of enterprises in such a policy environment and the implications for efficiency improvement and productivity growth, we may suppose that industries that are mainly supported by input subsidies could be more efficient and productive than those that are subject to administrative interference. We argue that when subsidies do not come with administrative interference in business decisions, enterprises may still behave like true market competitors although their competitiveness is arbitrarily enhanced by the cheaper cost of some factors influenced by the Government. ${ }^{2}$

In contrast, the upstream industries are far from the end market. They are traditionally dominated by SOEs and do not conform to China's comparative advantage. Their assumed 'strategic importance', however, gives them strong bargaining power in negotiating for government support and in return they have to accept controls by the authorities. This distorts their behaviour and is a disincentive in their efforts towards efficiency improvement.

2 This is conditional on whether they can repeatedly negotiate for benefits regardless of their true performance. Here we assume this is not the case. 
The nature of government interventions is cross-subsidisation; however, the key to sustain this 'cross-subsidisation game' is that the income of the downstream industries must be able to grow faster and relatively more efficiently than the rise of the cost due to all kinds of subsidies, to either the upstream or the downstream industries.

\section{Measuring total factor productivity}

In this study, we estimate China's industrial TFP growth with the Jorgensonian growth accounting approach in which primary and intermediate inputs are weighted in their nominal costs, coherently linked to factor income accounts in the national input-output framework. This approach is theoretically underpinned by the seminal contribution of Jorgenson and Griliches (1967). It is put in a more general input-output framework in Jorgenson et al. (1987) and further developed in Jorgenson et al. (2005). ${ }^{3}$ It begins with consideration of the production possibility frontier where industry gross output is a function of capital, labour, intermediate inputs and technology indexed by time. Each industry, indexed by $j$, can produce a set of products and purchases a number of distinct intermediate capital and labour inputs to produce its output. The production function is given by Equation 17.1.

Equation 17.1

$$
Y_{j}=f_{j}\left(K_{j^{\prime}} L_{j^{\prime}}, M_{j^{\prime}} T\right)
$$

In Equation 17.1, $Y$ is output, $K$ is an index of capital service flows, $L$ is an index of labour service flows and $X$ is an index of intermediate inputs, either purchased from domestic industries or imported.

Under the assumptions of competitive factor markets, full input utilisation and constant returns to scale, the growth of output can be expressed as the costweighted growth of inputs and technological change $\left(A^{Y}\right)$, using the trans-log functional form (Equation 17.2).

Equation 17.2

$$
\Delta \ln Y_{j t}=\bar{v}_{j t}^{K} \Delta \ln K_{j t}+\bar{v}_{j t}^{L} \Delta \ln L_{j t}+\bar{v}_{j t}^{M} \Delta \ln M_{j t}+\Delta \ln A_{j t}^{Y}
$$


In Equation 17.2, $\bar{v}_{j t}^{K}=\frac{P_{j t}^{K} K_{j t}}{P_{j t}^{Y} Y_{j t}}, \bar{v}_{j t}^{L}=\frac{P_{j t}^{L} L_{j t}}{P_{j t}^{Y} Y_{j t}}$ and $\Delta \ln X_{j t}=\sum_{m} \bar{w}_{m, j t}^{M} \Delta \ln M_{m, j t}$ are weights in normal costs for respective input, and $\bar{v}_{j t}^{K}+\bar{v}_{j t}^{L}+\bar{v}_{j t}^{M}=1$. Each input as expressed in the right-hand side of Equation 17.2 indicates the proportion of output growth accounted for by the growth of intermediate materials, capital services, labour services and technology or TFP, respectively.

One of the advantages of this approach is that it can better account for services provided by different types of labour due to different demographic, educational and industrial attributes. This has relaxed the usual strong assumption that treats numbers employed or hours worked as a homogenous measure of labour input. We define total labour input as a Törnqvist quantity index of individual labour types as follows (Equation 17.3).

Equation 17.3

$$
\Delta \ln L_{j t}=\sum_{h} \bar{w}_{h, j t}^{H} \Delta \ln H_{h, j t}
$$

In Equation 17.3, $\Delta \ln H_{h, j t}$ indicates the growth of hours worked by each labour type, $h$ (with specific gender, age and education attainment), and their cost weights, $\bar{w}_{h, j t}^{H}$, given by the period average shares of each type in the value of labour compensation controlled by the labour income accounts as in the input-output accounts. This approach ensures that the effect of demographic change on the economy can be properly counted. The same user cost approach is also applied to $K\left(\Delta \ln K_{j t}=\sum_{k} \bar{w}_{k, j t}^{K} \Delta \ln K_{k, j t}\right)$ and $X$ $\left(\Delta \ln X_{j t}=\sum_{m} \bar{w}_{m, j t}^{M} \Delta \ln M_{m, j t}\right)$ to fully account for different types of capital assets and intermediate inputs in production.

Next, we consider using the Domar aggregation approach to examine whether and to what extent the productivity performance of downstream industries has sustained the cross-subsidisation game and whether and to what extent the productivity performance of upstream industries has affected the cost of downstream industries through input-output linkages, hence influencing the productivity performance of the whole industry.

The Domar aggregation approach was first proposed by Domar (1961) and further elaborated by Hulten (1978). The idea is that for an industry-wide equivalent, we can postulate the existence of an industry-wide production possibility frontier (PPF) that relates available primary factor inputs to deliveries to the final demand. An aggregate productivity change is then defined as a shift of the aggregate PPF over time, or the rate of change in A - that is, TFP- 
which can be measured as the difference between the rate of change in total final demand $(F D)$ and the rate of change in the input of primary factors $(Z=L$ $\times K)$ and intermediate inputs from domestic sources $\left(M_{D}\right)$ and abroad (imported) $\left(M_{M}\right)$. The Domar aggregation is expressed in Equation 17.4.

Equation 17.4

$$
\frac{d \ln A}{d t}=\sum_{j} \frac{P^{j} Q^{j}}{P \cdot F D} \cdot \frac{d \ln A^{j}}{d t}
$$

In Equation 17.4,

$$
\frac{d \ln A^{j}}{d t}=\frac{d \ln Q^{j}}{d t}-\frac{P^{j} Z^{j}}{P^{j} Q^{j}} \cdot \frac{d \ln Z^{j}}{d t}-\frac{P^{j}{ }_{M D} M_{D}^{j}}{P^{j} Q^{j}} \cdot \frac{d \ln M_{D}^{j}}{d t}-\frac{P^{j}{ }_{M M} M_{M}^{j}}{P^{j} Q^{j}} \cdot \frac{d \ln M_{M}^{j}}{d t} .
$$

A direct consequence of this integration is that the weights do not sum to unity, implying that aggregate productivity growth amounts to more or less than the weighted average of industry-level productivity growth. This reflects the fact that productivity change in the production of intermediate inputs not only has an 'own' effect, but also leads to reduced or increased prices in downstream industries, and that effect accumulates through vertical links.

This Domar aggregation approach is distinguished from the traditionally used aggregation approach that is based on simple weighted averages of industrylevel productivity growth, which does not account for the links between industries connected via flows of intermediate products. In the process of such integration, intra-industry deliveries are netted out to obtain productivity measures at a higher level of the economy. Conceptually, it treats every level of the aggregation as if it were a single unit of production with its specific technology and productivity pattern.

In the Domar aggregation, however, sectoral output coincides with final demand at the level of the entire economy. A consistent link is therefore established between industry-level and aggregate observations on productivity growth. The weights used for the aggregation are given by each industry's gross output relative to economy-wide value added. The sum of these weights is not necessarily equal to unity. Productivity gains of the integrated economy may exceed the average productivity gains across industries because flows of intermediate inputs between industries contribute to aggregate productivity by allowing productivity gains in successive industries to augment one another. The same logic can explain productivity losses. 


\section{Data, industry grouping and periodisation}

In this growth accounting exercise, I use a newly completed dataset for Chinese industry from a series of studies by my associates and me (see Wu 2008, 2014b; Wu and Yue 2012; Wu et al. 2014; Ito and Wu 2013; Wu and Ito 2014). The data are constructed in line with the principles for the production function analysis in the above-discussed Jorgenson-Griliches framework. It satisfies all the empirical requirements of Equations 17.2 to 17.4. It covers China's entire reform period, from 1980 to 2010, which also allows us an examination of the effect of the 2008 GFC and its aftermath.

To investigate the TFP performance of industries located in different positions in the production chain, which may be subject to different degrees of government intervention, we categorise 21 mining, manufacturing and utility industries into four groups. They are 'energy', 'commodities and primary input materials' (C\&P), 'semifinished goods' and 'finished goods'. ${ }^{4}$ According to their 'distance' from final demand, the 'energy' group stays on the top of the production chain, which is followed by the 'C\&P' group, the 'semifinished goods' and finally the 'finished goods' groups. According to the technological nature of different groups, the 'finished goods' group is more labour intensive than the upstream groups, and hence more in line with China's comparative advantage. Therefore, it should be more productive than others.

This grouping aims to reflect the different methods and degrees of government intervention as hypothesised. The 'energy' group is monopolised by SOEs due to its strategic importance, and therefore receives more administrative interference or stronger state intervention. The ' $\mathrm{C} \& \mathrm{P}^{\prime}$ group is the next most important group that is also heavily influenced, if not owned, by the Government. The 'semifinished goods' group is to some extent similar to the 'C\&P' group, especially heavy machinery industry, which is also subject to varied state interference. Finally, the 'finished goods' group consists of mainly private enterprises including foreign-invested enterprises. Since the last two groups, especially the 'finished goods' group, are closer to the market, I suggest government intervention tends to be more indirect or less administrative, which leaves more room for enterprises to engage in market competition.

4 The 'energy' group includes coalmining, oil and gas extraction, petroleum refining, and utility supply; the 'commodities and primary input materials' group includes metal mining, nonmetallic mining, textiles, paper and printing, basic chemicals, building materials and primary metals; the 'semifinished goods' group includes metal products, machinery, electrical equipment, instruments, and office equipment; and the 'finished goods' group includes food, apparel, leather goods, electronic and telecommunications equipment, and transport equipment. I use quotation marks to indicate that this grouping is by no means a clear cut between groups, especially between the downstream groups. Besides, as in my earlier exercises (Wu 2013; Wu with Girardin 2013), I also exclude three industries in this grouping: tobacco, sawmill and wood products, and miscellaneous manufacturing. 
To examine the impact of major policy regime shifts on Chinese industry we can also divide the entire period 1980-2010 into four sub-periods - namely, 1980-91, 1992-2001, 2002-07 and 2008-10. The first sub-period covers early industrial reforms, though nationwide industrial reform began in 1984 with the dual-track price reform. This period experienced various institutional shocks as well as the political turmoil of 1989. The second sub-period began with Deng Xiaoping's call for bolder reform and the official adoption of a 'socialist market economy', which kicked off serious reforms to the state sector. This was followed by China's post-World Trade Organisation (WTO) period during which there were, however, mixed changes. On one hand, WTO-induced wider opening to foreign trade and direct investment moved China further towards the market system; on the other hand, consolidated and enlarged state corporations made a resurgence and, meanwhile, growth-motivated local governments became more involved in local business. The last sub-period began with the GFC, during which the role of the state was further enhanced by its unprecedented fiscal injection.

\section{Results and discussion}

\section{Descriptive observations}

Before proceeding to more rigorous growth accounting analysis, an examination of the indicators presented in Tables 17.1 to 17.4 may help explore the underlying efficiency and productivity performances of Chinese industry and its major groups. Let us start with the indicators presented in Table 17.1. There are some observations that are worth noting. First, for industry as a whole over the entire period under examination, net investment, as reflected by the increase in net capital stock (net K), grew faster than gross value added (VA), suggesting that China's post-reform industrial growth was on average driven by investment. Before reaching a nearly 15 per cent annual growth rate post WTO accession (2002-07), industrial net investment maintained a steady rate of growth of about 10 per cent a year during the 1980s and 1990s. The next, perhaps unprecedented, investment drive due to the Government's fiscal injection was observed in the wake of the GFC, which resulted in net capital stock growth of nearly 19 per cent per annum in 2008-10. 


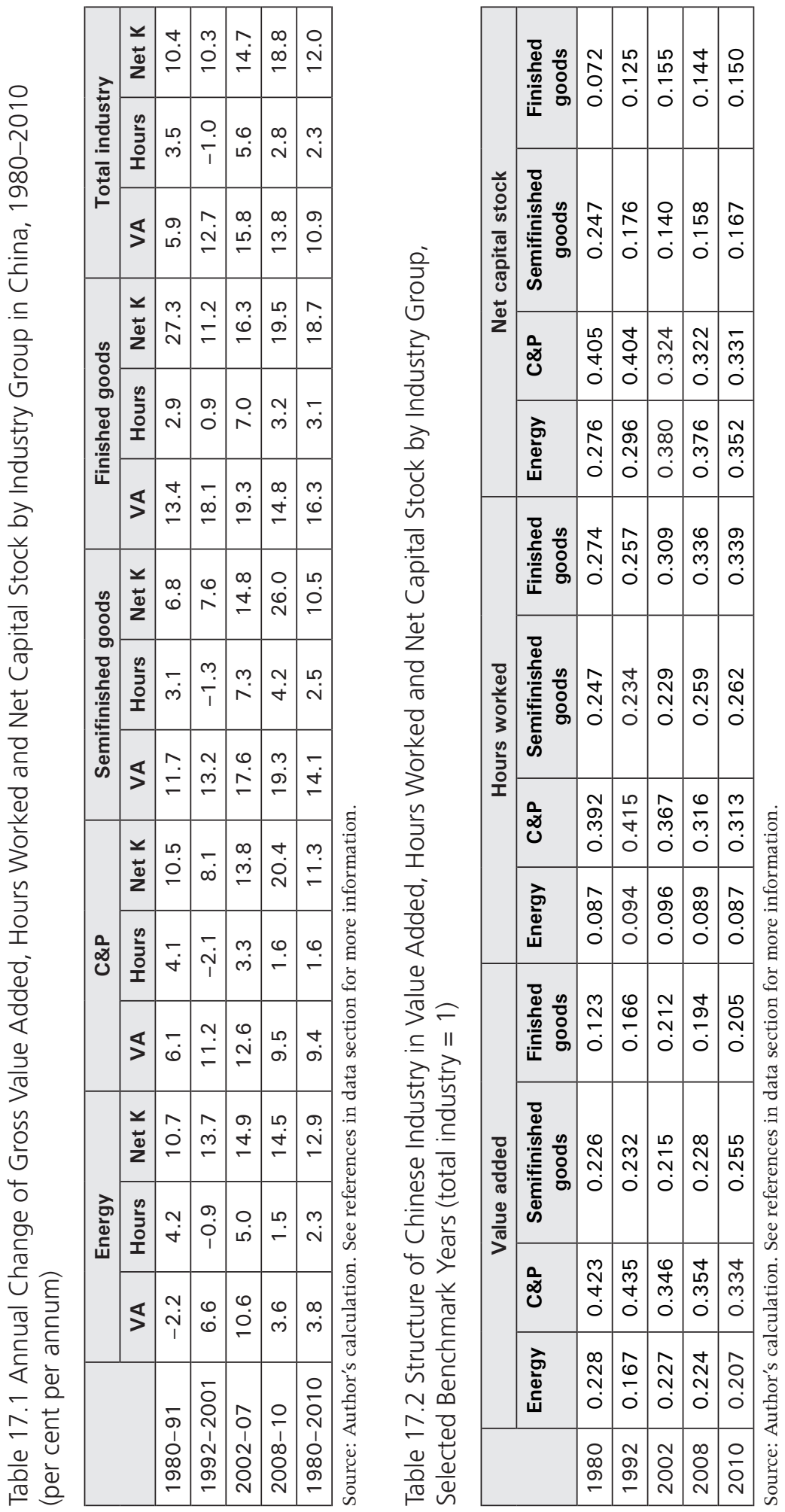


If broken down by industry group, the 'finished goods' group experienced the most rapid growth in net investment over the entire period-18.7 per cent a year - followed by the 'energy', 'C\&P' and 'semifinished' groups, respectively. If observed by sub-periods, the 'finished' group was well ahead of all others in China's post-WTO period and the 'energy' group took the lead during China's reform in the 1990s. Following the GFC in 2008, however, the growth in net investment of the 'semifinished goods' group reached 26 per cent a yearunprecedented by any standard.

Our second observation emphasises the relative annual growth rates between output and capital stock by sub-period, which may shed important light on the underlying inefficiency problem. For industry as a whole, the most 'efficient' sub-period appears to be the one beginning with Deng Xiaoping's trip to southern China in 1992 calling for bolder reforms, in which the industrial value added grew 24 per cent faster than that of industrial net investment. In the next most efficient period, however, following China's WTO entry, this favourable 'relative pace' between the two indicators declined substantially, to 8 per cent. On the opposite side, the initial reform period was the most 'inefficient', in which the annual growth of industrial value added was 43 per cent slower than that of industrial net investment. Such a mismatch was also evident following the GFC, when the former was significantly behind the latter by about 25 per cent.

At group level, using the same yardstick of 'relative pace' between output and net investment, the best performers appear to be the 'semifinished' and 'finished' groups over the 1990s and the post-WTO period. It should be noted that the record fiscal injection in response to the GFC forced the growth of net investment far ahead of the growth of value added in all groups, among which the state-monopolised 'energy' group appears to be most inefficient.

Third, we find that the performance of employment (measured by hours worked) was unstable over the entire period, reflecting the impact of rapid changes in both institutional and market conditions. On average, China maintained positive growth in employment over the period, by 2.3 per cent per annum; however, the total number of hours worked fluctuated highly from an absolute decline of -1 per cent per annum in 1992-2001 to annual growth of 5.6 per cent per annum in 2002-07. Such changes may reflect a significant improvement of serious labour redundancy and misallocation problems nurtured and developed under central planning. Indeed, healthy labour reallocation is reflected by the absolute decline in 1991-2001 across all groups except the 'finished goods' group that is more in line with China's comparative advantage. Another sign is the difference in the change of hours worked among industry groups following China's WTO entry, ranging from 3 per cent per annum in ' $\mathrm{C} \& \mathrm{P}^{\prime}$ to more than 7 per cent per annum in 'semifinished' and 'finished'. 
Table 17.2 shows the structure of gross value added, hours worked and net capital stock by industry group in selected benchmark years. As a consequence of different growth performances among groups over sub-periods, China's industrial structure has changed substantially. Here, let us focus on the structural change by more than 5 percentage points (ppts) in either direction. For the entire period, the structural change in capital stock was somewhat balanced between similar declines in 'C\&P' (-7.4 ppts) and 'semifinished' (-8 ppts) and similar increases in 'energy' (+7.5 ppts) and 'finished' (+7.8 ppts). For sub-periods, the most significant structural changes in either direction took place in the period 1980-91, with 'semifinished' dropping by 7.2 ppts and 'finished' increasing by 5.2 ppts, and in the period 1992-2001, with 'energy' rising by 8.4 ppts and 'C\&P' dropping by 7.4 ppts (all calculated based on Table 17.2).

On the other hand, the major structural changes in gross value added mainly took place in ' $\mathrm{C} \& \mathrm{P}^{\prime}$ and 'finished', with a drop of 9 ppts in the former and a rise by 8.2 ppts in the latter for the entire period. For sub-periods, however, the major structural changes could be observed mainly in 'energy' by -6.1 ppts in 1980-91 and in 'C\&P' by -8.9 ppts and in 'energy' by +6 ppts in 1992-2001. The major structural changes in hours worked, however, took place between the decline in ' $\mathrm{C} \& \mathrm{P}^{\prime}$ ' and the rise in 'finished', reflecting the labour-intensive nature of the latter and perhaps continuous technological upgrading in the former.

To continue our exploration through descriptive observations, in Tables 17.3 and 17.4 we present labour productivity (Y/L), the capital-labour ratio $(\mathrm{K} / \mathrm{L})$ and capital-output ratio $(\mathrm{K} / \mathrm{Y})$ in both level and growth rate, respectively. Here, Y/L is calculated by value added per worker, standardised using constant numbers of hours worked per year (2400 hours) to control for homogeneity in physical intensity. The denominator in the capital deepening measure, K/L, follows the same approach for consistency. Besides, $\mathrm{K} / \mathrm{Y}$ is the ratio of $\mathrm{K} / \mathrm{L}$ to $\mathrm{Y} / \mathrm{L}$. Note that the quality of labour and capital has not yet been controlled at this stage (see TFP analysis later).

Based on the level indicators presented in Table 17.3, the most significant observation is that the labour productivity (Y/L) of 'semifinished' had surpassed the $\mathrm{Y} / \mathrm{L}$ ratio of 'energy' and 'C\&P' by 2002. Meanwhile, the $\mathrm{Y} / \mathrm{L}$ ratio of 'finished' had almost reached the same level as 'C\&P'. Such trends continued in the following decade, and by 2010, the Y/L ratio of 'semifinished' had not only remained highest among all groups, but also doubled the level of 'energy'. In the same period, the $\mathrm{Y} / \mathrm{L}$ ratio of 'finished' had surpassed that of 'C\&P' by about 15 per cent. 
Deepening Reform for China's Long-Term Growth and Development

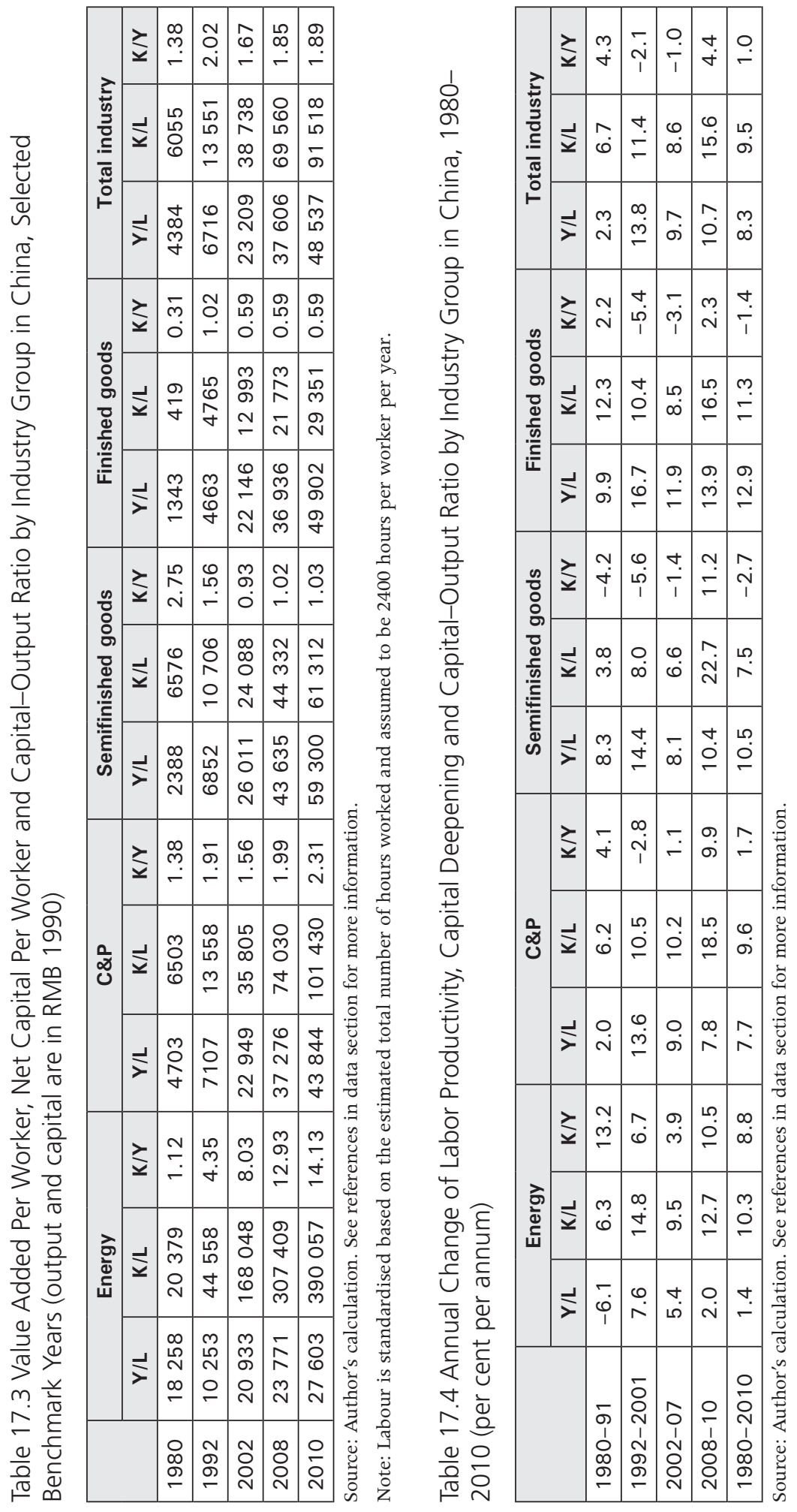




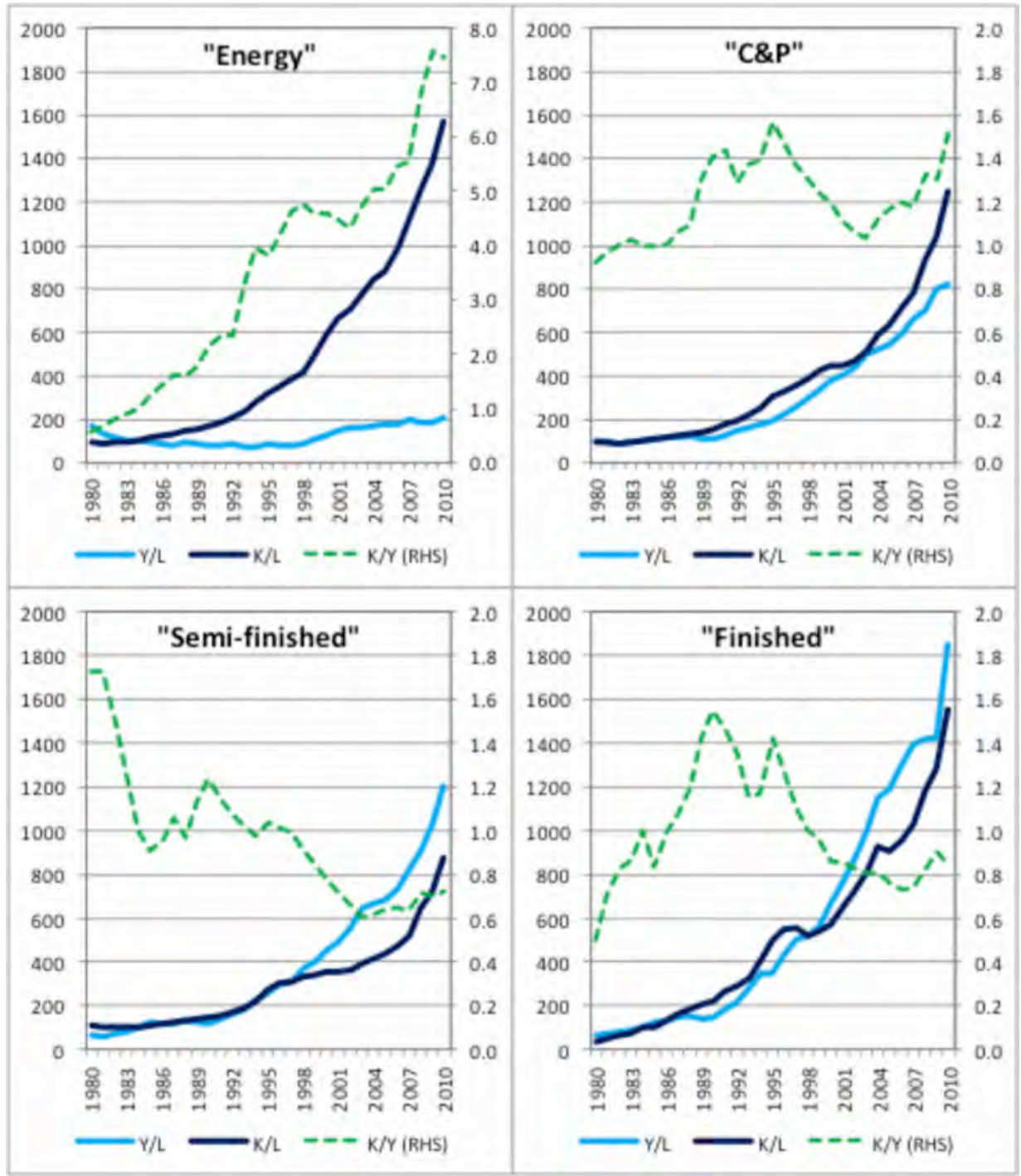

Figure 17.1 Indices of Labour Productivity, Capital Deepening and Capital-Output Ratio by Industry Group (1984 = 100)

Source: Author's calculation.

Notes: $\mathrm{K} / \mathrm{Y}=(\mathrm{K} / \mathrm{L}) /(\mathrm{Y} / \mathrm{L}) ; 1984=1$ (on the right-hand scale).

More importantly, alongside these changes, the capital-labour ratio (K/L) of 'semifinished' remained only about 15 per cent of the level of 'energy', and declined from about 80 to 60 per cent of the level of 'C\&P'. The K/L ratio of 'finished goods' was the lowest of all groups and declined from 54 to 48 per cent of the K/L level of 'semifinished'. Consequently, the capital-output ratio $(\mathrm{K} / \mathrm{Y})$ of 'semifinished' and 'finished' stayed at a very low level of around 1 and 0.6 , respectively, since 2002. Meanwhile, the K/Y ratio of 'energy' reached an 
astonishingly high level of 14 . The annual changes of these ratios over the entire period and its sub-periods are provided in Table 17.4. It shows that the 'finished goods' group, in which China has enjoyed strong comparative advantage and benefited from the demographic dividend, was the most dynamic group in both labour productivity and capital deepening. To help the examination in a continuous time frame, Figure 17.1 depicts the growth index of these ratios based on 1984, which was when the nationwide industrial reform began.

\section{Total factor productivity performance}

The growth of TFP for Chinese industry can be calculated in a growth accounting exercise based on Equations 17.2 to 17.4 with and without considering inter-industry connections. The estimation procedures are followed at two levels. The first level is the individual group level at which all industries within the group are treated as identical and in one unit. In other words, there is no intra-group relationship that is considered. The second level is China's total industry. At this level, two sets of TFP growth estimates are obtained using the Domar and non-Domar aggregations. The estimation of the Domar-weighted TFP growth for total industry considers a cumulative productivity effect from upstream to downstream industries, whereas the estimation of the traditional or non-Domar TFP growth treats all groups as identical in one enlarged economywide unit.

In Table 17.5, we show the growth of each input factor weighted by its nominal costs (with their sum equal to the national gross value of output in industry from the national accounts). The residual so derived is the estimated TFP growth rate for each group as well as for industry as a whole. It should be mentioned again that in this estimation, as given by Equation 17.3, both labour and capital are measured in their services rather than in physical units. This ensures that quality change in labour and capital is not inappropriately measured as TFP change. 
Table 17.5 Accounting for the Sources of Gross Output Growth in Chinese Industry by Industry Group (per cent per annum)

\begin{tabular}{|c|c|c|c|c|c|c|}
\hline & GO & $L$ input & $K$ input & $M$ input & TFP & $\begin{array}{c}\text { TFP } \\
\text { (Domar) }\end{array}$ \\
\hline & \multicolumn{6}{|c|}{ 1980-91 } \\
\hline Energy & 0.9 & 0.4 & 3.5 & 1.9 & -4.9 & \\
\hline$C \& P$ & 7.9 & 0.4 & 2.4 & 5.9 & -0.8 & \\
\hline Semifinished & 13.6 & 0.3 & 1.5 & 9.7 & 2.0 & \\
\hline Finished & 13.7 & 0.2 & 2.6 & 10.5 & 0.3 & \\
\hline \multirow[t]{2}{*}{ Total (new) } & 8.6 & 0.3 & 2.4 & 6.7 & -0.8 & -2.0 \\
\hline & \multicolumn{6}{|c|}{$1992-2001$} \\
\hline Energy & 7.0 & -0.1 & 3.4 & 4.7 & -1.0 & \\
\hline$C \& P$ & 11.0 & -0.2 & 1.4 & 8.0 & 1.7 & \\
\hline Semifinished & 13.6 & 0.0 & 1.2 & 10.4 & 2.0 & \\
\hline Finished & 16.3 & 0.1 & 1.8 & 12.3 & 2.2 & \\
\hline \multirow[t]{2}{*}{ Total (new) } & 12.7 & 0.0 & 1.8 & 9.4 & 1.5 & 5.0 \\
\hline & \multicolumn{6}{|c|}{ 2002-07 } \\
\hline Energy & 15.0 & 0.3 & 3.2 & 11.7 & -0.2 & \\
\hline C\&P & 15.2 & 0.1 & 2.1 & 12.3 & 0.8 & \\
\hline Semifinished & 19.7 & 0.4 & 2.0 & 15.9 & 1.4 & \\
\hline Finished & 22.0 & 0.4 & 2.0 & 18.2 & 1.4 & \\
\hline \multirow[t]{2}{*}{ Total (new) } & 18.8 & 0.3 & 2.2 & 15.1 & 1.2 & 2.3 \\
\hline & \multicolumn{6}{|c|}{ 2008-10 } \\
\hline Energy & 2.4 & 0.1 & 2.6 & 1.5 & -1.7 & \\
\hline$C \& P$ & 8.9 & 0.1 & 2.8 & 6.9 & -0.8 & \\
\hline Semifinished & 18.0 & 0.1 & 2.9 & 14.5 & 0.5 & \\
\hline Finished & 14.0 & 0.2 & 2.3 & 11.4 & 0.2 & \\
\hline \multirow[t]{2}{*}{ Total (new) } & 13.3 & 0.1 & 2.5 & 10.5 & 0.2 & -2.3 \\
\hline & \multicolumn{6}{|c|}{ 1980-2010 } \\
\hline Energy & 5.9 & 0.2 & 3.3 & 4.8 & -2.4 & \\
\hline$C \& P$ & 10.5 & 0.1 & 2.1 & 8.0 & 0.3 & \\
\hline Semifinished & 15.3 & 0.2 & 1.6 & 11.6 & 1.8 & \\
\hline Finished & 16.3 & 0.2 & 2.2 & 12.7 & 1.1 & \\
\hline Total (new) & 12.5 & 0.2 & 2.2 & 9.7 & 0.5 & 1.1 \\
\hline
\end{tabular}

Source: Author's estimation based on Equations 17.2-17.4.

Note: See text for Domar aggregation-derived TFP. 
Let us first examine China's industrial TFP growth performance, assuming there are no intra-group and inter-group effects - that is, without using the Domar weights at any level of the aggregation. As Table 17.5 shows, for industry as a whole over the entire period 1980-2010, TFP performance is disappointing, growing by only 0.5 per cent per annum. At the group level, the best performer is the 'semifinished goods' group, followed by the 'finished goods' group, with annual TFP growth by 1.8 and 1.1 per cent, respectively. The ' $\mathrm{C} \& \mathrm{P}^{\prime}$ group achieved annual TFP growth of just 0.3 per cent, while the 'energy' group suffered from a TFP decline by a shocking -2.4 per cent per annum.

Examining the performance over different sub-periods, for industry as a whole, the best period was 1992-2001, when the annual TFP growth rate reached 1.5 per cent. This result may reflect the Government's first efforts to adopt the ('socialist') market system and to implement de facto privatisation of some SOEs. Although the large and 'strategic' industries remained state-owned or controlled, the TFP effect of the reform appears to be rather encouraging. During this period the 'finished goods' group took the lead in TFP growth, by 2.2 per cent per annum, followed by the 'semifinished' group ( 2 per cent) and 'C\&P' group (1.7 per cent). In fact, the 'semifinished goods' group maintained its TFP performance in the previous period, 1980-91, whereas the 'C\&P' and 'finished goods' groups achieved a substantial improvement from their previous performance of -0.8 and 0.3 per cent annual TFP growth, respectively. Meanwhile, the 'energy' group experienced an annual TFP decline of -1 per cent, though much improved from its previous record of -4.9 per cent.

China's WTO entry was not, however, accompanied by a continuous TFP improvement as one may expect. The annual TFP growth for total industry fell to 1.2 per cent in 2002-07, although Chinese industry experienced its fastest output growth in history - that is, 18.8 per cent compared with 12.5 per cent in 1992-2001. Compared with the previous period, the annual TFP growth of the 'semifinished' and 'finished' groups slowed considerably, by about 30 per cent to 1.4 per cent, whereas the average TFP growth of the ' $\mathrm{C} \& \mathrm{P}^{\prime}$ group slowed by about 50 per cent to 0.8 per cent. Meanwhile, the 'energy' group somewhat improved its performance though it remained in the negative zone. As we argued earlier, the declining productivity performance of this period could be caused by the resurgence of large state corporations and the greater involvement of local governments in resource allocation. Nevertheless, this trend was enhanced by the unprecedented fiscal injection in the wake of the GFC.

Figure 17.2 provides a 1984-based TFP index for the entire period for each industry group as well as for industry as a whole. It resembles the results of different periods in Table 17.5 in time-series and helps compare the current TFP level with that in the base year. It shows that by 2010 the 'energy' group's TFP 
level was 40 per cent below its base-year level; the ' $\mathrm{C} \& \mathrm{P}^{\prime}$ ' group was 12 per cent above its base-year level, and the 'semifinished' and 'finished' goods groups were about 35 per cent of their original productivity level in 1984.

Our main concern is whether the state-dominated upstream industries have affected the productivity performance of Chinese industry as a whole. As argued, since upstream industries provide intermediate inputs to downstream industries, their productivity performance inevitably affects the TFP performance of downstream industries. This inter-industry effect on the annual TFP growth of industry as a whole can be examined by the Domar-aggregation approach as presented in the last column of Table 17.5, which is also indexed in Panel B of Figure 17.2.

If considering the inter-industry TFP effect, the entire period achieved annual TFP growth by 1.1 per cent (Table 17.5). The best TFP effect, transmitted from upstream to downstream industries, appears to be from the mid 1990s to the early 2000s, largely corresponding to the period 1992-2001. For this period, the Domar-weighted TFP grew by 5 per cent per annum compared with the nonDomar TFP growth of 1.5 per cent per annum. For the post-WTO period, 200207, however, the Domar-weighted TFP growth fell to 2.3 per cent per annum. During the period 2008-10, after the GFC, the 'energy' and 'C\&P' groups became the major beneficiaries of the Government's unprecedented monetary injection to save the economy. TFP in this period, however, suffered an annual decline by -2.3 per cent.

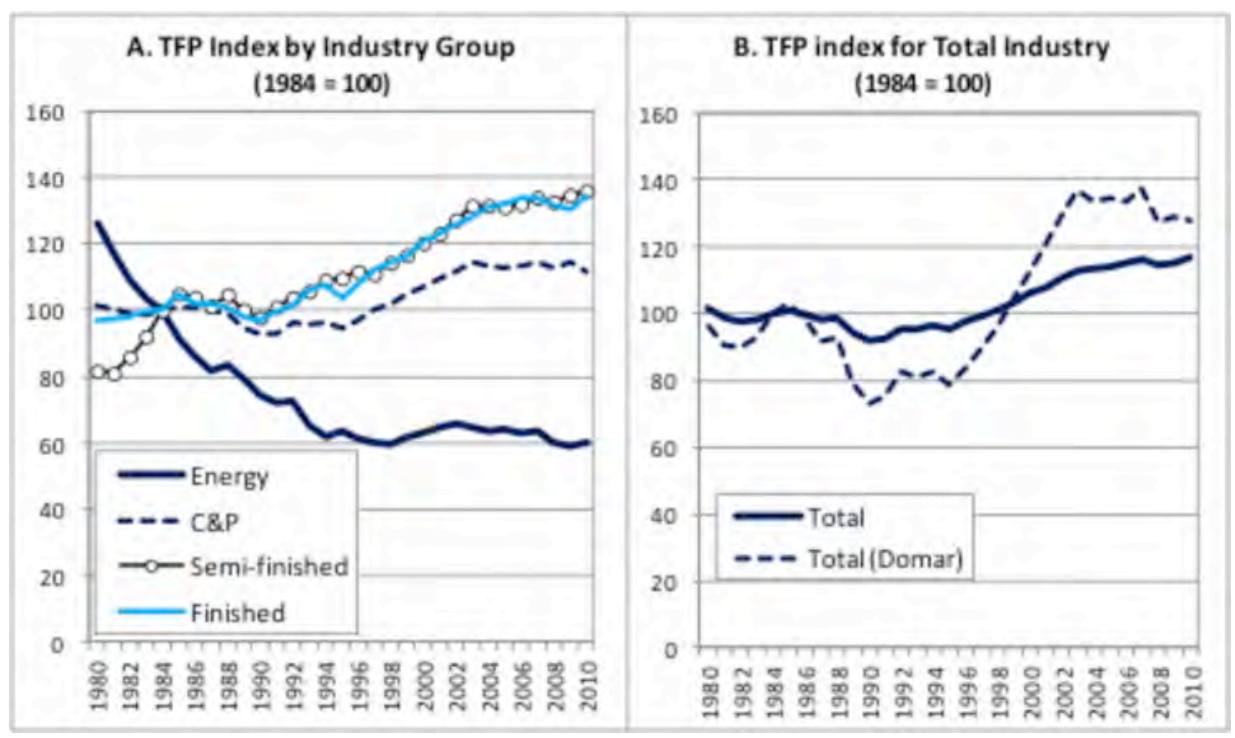

Figure 17.2 China's Industrial TFP Growth by Industry Group (1984=100)

Source: Constructed based on results in Table 17.5. 
Examining the two panels of Figure 17.2, it is clear that the 'semifinished' and 'finished' goods groups were the ones that sustained positive, albeit still slow, TFP growth in Chinese industry for the entire period. The better productivity performance of these two groups ensured a continuous increase in government revenue and hence a continuous flow of public resources to support inefficient upstream industries, which were required to provide subsidised inputs to make downstream industries more competitive. Indeed, we find that both the 'semifinished' and the 'finished' groups have become more and more reliant on intermediate inputs (Table 17.5). Without question, our broad grouping may not reflect the complete story of each industry within the group, but it reflects the average performance of each group. Obviously, without the 'semifinished' and 'finished' goods groups, the cross-subsidisation game cannot exist.

\section{Concluding remarks}

This study applies the Jorgenson-Griliches framework in growth accounting to a newly constructed industry-level dataset for China to examine the sources of growth in Chinese industry 1980-2010. In data handling, the quality improvement of labour and capital has been taken into account. At industry level, instead of using simple quantity measures for primary inputs and imposing hypothetical income shares for them, this approach uses cost-weighted measures for all inputs that are controlled by the national accounts and the input-output table-based time-variant factor income shares. At the aggregate level, using the Domar aggregation approach, it also takes into account the cumulated productivity effect from the upstream to downstream industries.

Our preliminary results show that the TFP growth of China's industrial sector as a whole for the entire period is only 0.5 per cent per annum. If based on the Domar aggregation approach, the estimate can be raised to 1.1 per cent per annum. The best sub-period appears to be the one from 1991 to 2001, with annual TFP growth of 1.5 per cent, or 5 per cent based on the Domar aggregation approach. This is followed by the second-best sub-period, 2001-07, with TFP growth of 1.2 per cent per annum, or 2.3 per cent based on the Domar approach.

China's industrial TFP performance is not respectable if compared with international experience, especially East Asian experience. If controlling for the stage of development by per capita GDP US\$2000 to US\$6000 measured in purchasing power parity (PPP) at 1990 prices (TCB 2013; Wu 2014a), and taking into account the general tendency for that TFP growth in the industrial sector to be faster than that of the national economy (as most available TFP studies focus on national economy), China's annual TFP growth in industry would be 1.2 per cent (1992-2010) - much lower than Japan's 4.4-5.1 per cent for its national 
economy (1950-73), based on Maddison (1995) and Wolff (1996). Besides, South Korea's TFP growth in manufacturing could be 3 per cent per annum in 1966-90 if based on Young (1995). Taiwan's industrial TFP growth could be gauged at between 3 and 5 per cent per annum if based on Young (1995) and Kawai (1994).

Although semifinished and finished goods industries have maintained slow TFP growth in the past three decades, the persistent TFP decline in energy industries and deteriorating TFP performance in industries that produce input materials have clearly suggested that the cross-subsidisation between the upstream and downstream industries through government interventions is absolutely unhealthy and unsustainable. We also show that the downstream industries have been relying more and more on intermediate inputs. Therefore, the efficiency and productivity of the latter inevitably have a significant bearing on the cost of the former. This is a fundamental problem facing the Chinese economy that should be addressed seriously in the current policy debate.

\section{References}

Bosworth, B. and Collins, S. M. (2008), 'Accounting for growth: comparing China and India', Journal of Economic Perspectives 22(1): 45-66.

Domar, E. (1961), 'On the measurement of technological change', Economic Journal 71.

Huang, Y. and Tao, K. (2010), 'Factor market distortion and the current account surplus in China', Asian Economic Papers 9(3).

Hulten, C. (1978), 'Growth accounting with intermediate inputs', Review of Economic Studies 45.

Ito, K. and Wu, H. X. (2013), Construction of China's input-output table time series for 1981-2010: a supply-use table approach, Presented at the Second Asia KLEMS Conference, Bank of Korea, Seoul, 22-23 August 2013.

Jorgenson, D. W. and Griliches, Z. (1967), 'The explanation of productivity change', Review of Economic Studies 34(3): 249-83.

Jorgenson, D. W., Gollop, F. and Fraumeni, B. (1987), Productivity and U.S. Economic Growth, Cambridge, Mass.: Harvard University Press.

Jorgenson, D. W., Ho, M. S. and Stiroh, K. J. (2005), Information Technology and the American Growth Resurgence, Cambridge, Mass.: MIT Press. 
Kawai, H. (1994), 'International comparative analysis of economic growth', The Developing Economies XXXII(4): 373-97.

Maddison, A. (1995), Monitoring the World Economy, 1820-1992, Paris: OECD Development Centre.

O'Mahony, M. and Timmer, M. P. (2009), 'Output, input and productivity measures at the industry level: the EU KLEMS database', The Economic Journal 119(June): F374-F403.

The Conference Board (TCB) (2013), Total Economy Database, New York: The Conference Board.

Wolff, E. N. (1996), 'The productivity slowdown: the culprit at last? Follow-up on Hulten and Wolff', American Economic Review 86(5): 1239-52.

Wu, H. X. (2008), Measuring capital input in Chinese industry and implications for China's industrial productivity performance, 1949-2005, Presented at the World Congress on National Accounts and Economic Performance Measures for Nations, Washington, DC.

Wu, H. X. (2013), Accounting for productivity growth in Chinese industrytowards the KLEMS approach, Presented at the Second Asia KLEMS Conference, Bank of Korea, Seoul, 22-23 August 2013.

Wu, H. X. (2014a), China's growth and productivity performance debate revisited accounting for China's sources of growth in 1949-2012, Economics Working Papers EPWP1401, The Conference Board, New York.

Wu, H. X. (2014b), Constructing China's net capital stock and measuring capital service in China, Presented at CIP Special Project Meeting, IER, Hitotsubashi University, Tokyo, 20 March 2014.

$\mathrm{Wu}, \mathrm{H} . \mathrm{X}$. and Ito, K. (2014), Reconstruction of China's national output and income accounts, producer price indices, and annual supply-use and inputoutput accounts, Presented at CIP Special Project Meeting, IER, Hitotsubashi University, Tokyo, 20 March 2014.

Wu, H. X. and Yue, X. (2012), Accounting for labor input in Chinese industry, 1949-2009, Discussion Paper Series 12-E-065, RIETI, Japan.

Wu, H. X., with Girardin, E. (2013), China's growth cycles: common features of GDP and coincident economic indicators, Presented at Ninth CERDI-IDREC International Conference on the Chinese Economy, University of Auvergne, Clermont-Ferrand, France, 24-25 October 2013. 
Wu, H. X., Yue, X. and Zhang, G. G. (2014), Constructing employment and compensation matrices and measuring labor input in China, Presented at CIP Special Project Meeting, IER, Hitotsubashi University, Tokyo, 20 March 2014.

Wu, Y. (2011), "Total factor productivity growth in China: A review", Journal of Chinese Economic and Business Studies 9(2), 111-126.

Young, A. (1995), 'The tyranny of numbers: confronting the statistical realities of the East Asian growth experience', Quarterly Journal of Economics (August): 641-80. 
This text taken from Deepening reform for China's long-term growth and development, edited by Ligang Song, Ross Garnaut, Cai Fang, published July 2014 by ANU Press, The Australian National University, Canberra, Australia. 